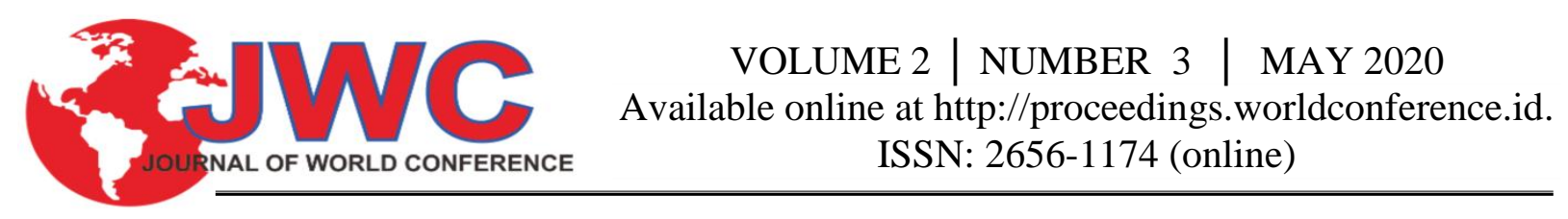

\title{
Analysis of Use of Welded Angle and Drop Hollow as Reusable Temporary Supporting in Metal deck Slabs Viewed from Performance of Costs and Time
}

\author{
Novika Candra Fertilia dan Sani Sona Swasti \\ Faculty of Engineering, University Mercu Buana Jakarta, Indonesia \\ novikacandraf@yahoo.com, sanisona500@gmail.com
}

\begin{abstract}
Like the project in general, slab work on Project Indonesia 1 uses one material, namely metal deck. The upper structure slab consists of 64 floors with a majority of $90 \%$ using a metal deck system. Where these components require support that can carry the workload, rebar, and fresh concrete. Starting with Metaldeck's non-reusable / fixed supporting (angle \& anchor) design which is quite difficult to apply in the field, it has an impact on increasing time and increasing the cost of work. So the engineering team has the innovation of replacing non-reusable / fixed supporting material (angle \& anchor) with reusable material (angle \& drop hollow). Cost analysis is sought by calculating the RAB (Cost Budget Plan) using the unit price analysis used by the DKI Jakarta Government and how efficient the time gained. Based on the results of calculations and interviews with relevant experts on the project, the implementation of temporary supporting work costs was carried out using a non-reusable method of Rp.3,211,000,000.00. As for the implementation of the reusable method of Rp.649,916,800. There is a difference in cost between the non-reusable and reusable methods of Rp. 2,561,083,200.00. Where to implement the temporary supporting reusable method is cheaper than using the non-reusable initial method. Then in terms of installation time, the temporary supporting using the non-reusable method was 520 days while for the reusable method it was 260 days. There is a difference between the non-reusable and 260-day reusable methods. The results obtained that the use of Welded Angle \& Drop Hollow as Temporary Supporting is more effective and efficient than using the initial Non-reusable method.
\end{abstract}

Keywords

Metal deck, Temporary Supporting, Time Deviation, Cost Deviation.

\section{Introduction}

\subsection{BACKGROUND}

From year to year building construction in Indonesia is growing, especially in the world of construction. The increasing number of construction service providers lately should be offset by cost savings, quality in accordance with the standards and also the efficiency of the project work time. In Indonesia currently competing in the construction of high-rise buildings. And one of them is the Indonesia 1 Jakarta building. Acting as the main contractor of PT Acset Indnusa, tbk conducted a Joint Operation with CCEED (China State Construction Engrg. Corp. Ltd).

The construction of the Indonesia 1 Jakarta building is one of the high-rise building projects that will become one of the tallest buildings in Indonesia. This building has two towers. Covering 58 floors, lower roof, roof top with helipad, (Tower North) \& 59 floors, lower roof, roof top (Tower South), 7 basements and will also have bridges connecting the two towers. Because the main material used in the construction of Indonesia building 1 uses composite materials, it must really take into account the earthquake forces that occur. Regulated in the calculation of reinforced concrete structures which are in SNI 1726, ASTM A615, and ACI 318-14.

Like most projects in the slab Project Indonesia 1 uses one material, namely metaldeck. The upper structure slab consists of 58 floors with a majority of $90 \%$ using a metaldeck system. Where these components require a support that is able to carry the workload, rebar and fresh concrete. Starting from the Metaldeck non-reusable / fixed supporting design (angle \& anchor) which is quite difficult to apply in the field, it gives an impact on increasing time and increasing the cost of work. So the engineering team has the 
innovation of replacing non-reusable / fixed supporting material (angle \& anchor) with reusable material (angle $\&$ hollow drp). It is hoped that this innovation will save time and work costs without reducing the quality of supporting. Here will be discussed about Analysis of the Use of Welded Angle \& Drop Hollow as Reusable Temporary Supporting on Metaldeck Slab in Indonesia Project 1.

\subsection{IDENTIFICATION OF PROBLEMS}

Based on the background that the author has described, identification of problems based on observations in the field, namely:

The time needed for the installation of temporary support exceeds the specified schedule.

The process of implementing non-reusable / fixed suppoting metaldeck (angle \& anchor) is difficult to apply so reusable temporary support is needed to shorten the processing time.

The need for saving post in Temporary Supporting work.

\subsection{FORMULATION OF THE PROBLEM}

Based on the identification of the problem and so that the discussion is more directed according to its purpose, the problem is formulated as follows:

a) Can reusable temporary support improve time performance on Project Indonesia 1?

b) What are the benefits and costs if reusable temporary support is applied to Project Indonesia 1 ?

\subsection{PURPOSE AND OBJECTIVES}

The aims and objectives of this research are:

a. Knowing that using reusable temporary support can improve the time and cost performance of Project Indonesia 1.

b. Knowing how much profit is generated by the reusable temporary support method through detailed calculations.

\section{Methodology}

The preparation of the research water diagram is:

1) The author begins the research. At this stage the authors conducted research in the Indonesia 1 Jakarta building construction project.

2) The activity of identifying problems (evaluation) is carried out after a literature study and problem analysis. By identifying the problem, it is expected that the final task examiner will clarify what problems will be addressed in this final task, as well as the boundaries of the problem so that it can assess the problem efficiently.

3) In the process of carrying out this final task requires theoretical foundations that support the problem to be tested. Through library research in the form of scientific journals, papers, books and articles related to research topics. It is hoped that it can add to knowledge and learn basic theories that will be used as a reference.

4) Furthermore, the authors conducted primary data collection and secondary data needed to make this final project include:

Field observations and interviews

Related Photos

Daily record sheet

Project data

Books and journals

5) Data analysis is the process of calculating and planning comparative costs and duration of work using non-reusable fixed supporting material $(100 \times 100 \mathrm{~mm}$ steel) with welded angle \& drop hollow material $(50 \times 50 \mathrm{~mm})$ :

Method of Implementation

Analysis of the method here is in the form of a calculation of the

installation method of metaldeck along with a temporary suppoting reference to the analysis of the implementation of the full system 


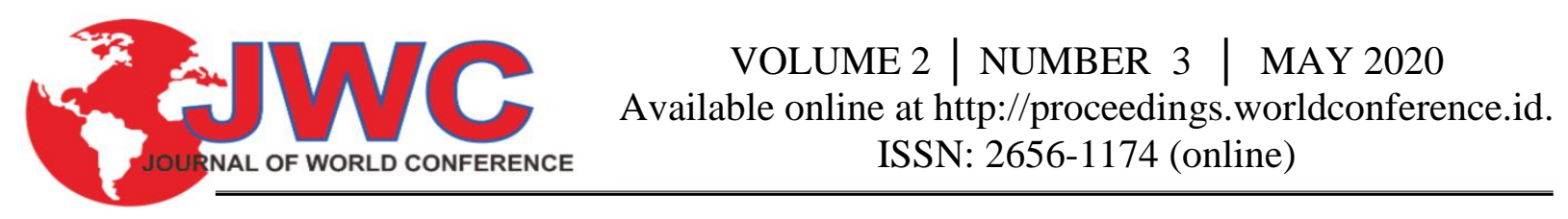

Implementation cost

In this stage, it will take into account the volume of each temporary support installation work of each non-reusable and re-usable material, then analyze the unit price of goods, work wages, and costs

Execution time

In the re-usable time of temporary supporting using welded angle \& drop hollow will be calculated what work is needed and analysis of the completion time in the project area so that the length of work planned. The analytical method I reviewed from the time of implementation of each temporary supporting system was obtained from direct observation in the field.

6) After analyzing the data obtained, conclusions can be drawn from the results of the analysis. This stage provides synchronization between the purpose of writing and the boundary of the problem with the analysis conducted, which is expected to be used as input for the readers.

7) Provide information about the study of the cost and time of the implementation of temporary supporting before using the reusable system and after reusable use in the Indonesian building project 1 . Research is completed

\section{RESULTS AND DISCUSSION}

\subsection{GENERAL REVIEW}

This chapter will discuss the process of analyzing the time difference and the cost of installing temporary supports using the non-reusable method (angle \& anchor) with the re-usable method (welded angle \& drop hollow). So that later it will be known which temporary supporting installation method is more efficient in terms of cost and time.

In this project the initial design is in accordance with the Indonesian building construction contract 1 using the initial method which is non-reusable. Where temporary supporting for metaldeck uses angle \& anchor while the initial material used is hollow $100 \mathrm{~mm} \times 100 \mathrm{~mm}$ besides the cost is quite expensive and heavy when carried out in the field. In the installation of temporary supporting non-reusable methods, it requires more than 2 people so that time efficiency is reduced.

From the field implementation, the contractor has re-evaluated, so that the installation of temporary support can be more effective and efficient. The contractor made an innovation where the non-reusable method (anchor \& angle) would be replaced using the reusable method (hollow 50x50mm \& angle) where. The re-usable method replaced the hollow material that had been 100x100mm with a hollow size of $50 \times 50 \mathrm{~mm}$. The re-usable system itself aims to make the installed hollow material reusable for the next floor. This reusable method is easier to apply in the field and saves enough money. In this chapter, we will explain further about the cost and time analysis of the two temporary supporting installation methods.

\subsection{ANALYSIS OF INSTALLATION TIME}

\subsubsection{Analysis of Non-reusable Ordering Time Methods}

Tabel 3.1 Perhitungan Total Waktu Pemasangan non-reusable dalam 1 Lantai

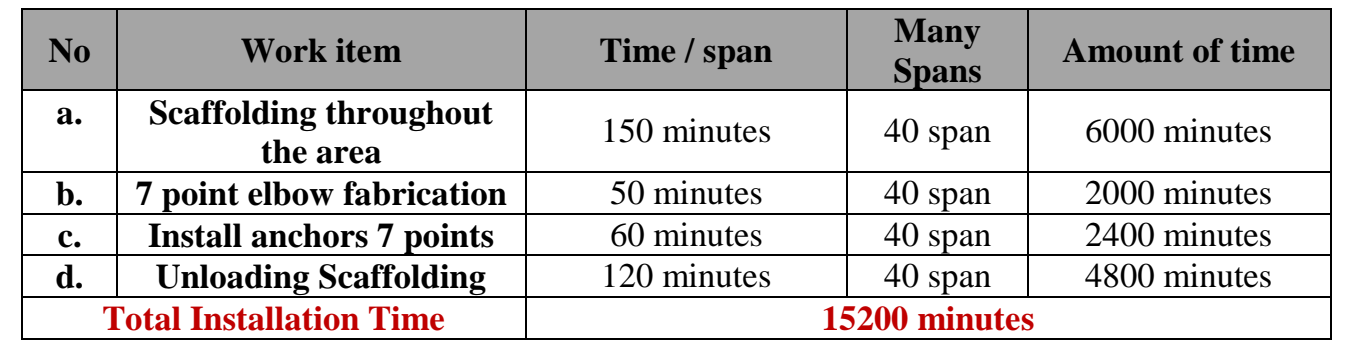

(Source :Data in Research Penulis,2020)

From Table 3.1 it can be concluded the total installation time for all temporary supporting work items using the non-reusable method per 1 floor is 15200 minutes. So that: 
Total Time for Completion of All Work Items per 1 Floor Using Non-reusable Method.

The total completion time for all items / hour;

$$
15.200 \text { minutes }=\frac{15.200 \text { minutes }}{60 \text { minutes }}=253 \text { hour }
$$

In 1 day there are 2 shifts, with each shift of workers is 8 hours so that the total working time is 16 hours.

$$
\begin{gathered}
\text { Total workmanship for } 1 \text { floor }=\frac{\text { The total turnaround time for all items }}{\text { worker hours }} \\
\text { Total workmanship for } 1 \text { floor }=\frac{253 \text { hours }}{16 \text { hours }}=16 \text { days }
\end{gathered}
$$

Kompensasi Perhitungan Overlaping Antara Zona Sesuai Gambar $4.3=$

$$
\text { Zone } \left.\mathrm{A} 1=\mathrm{A} 2=\mathrm{B} 1=\mathrm{B} 2=\frac{16 \text { hari }}{4 \text { hari }}=4 \text { hari }+2 \text { day(overlaping } / \text { zone }\right)=6 \text { day }
$$

Total Net Workmanship $=$ Total turnaround time - Kompensasi Overlaping

Total Net Workmanship $=16$ day -6 day

Total Net Workmanship / 1 Floor = 10 days

So that the Total Time Completion of All Temporary Supporting Work Items per 1 Floor Using Nonreusable Method is 10 days.

Table 3.2 Work on Temporary Supporting North \& South Tower

\begin{tabular}{|c|c|c|c|c|}
\hline No & $\begin{array}{c}\text { Floor Data Using } \\
\text { Metaldeck }\end{array}$ & $\begin{array}{c}\text { Number of floors } \\
\text { South \& } \\
\text { NorthTower }\end{array}$ & $\begin{array}{c}\text { Processing/ } \\
\text { Floor }\end{array}$ & Total Days \\
\hline 1. & 1 Upper -2nd Floor & 2 floor & 10 days & 20 days \\
\hline 2. & 3rd -5th Floor & Slab Konvensional & - & - \\
\hline 3. & 5th-19th Floor & 14 Lantai & 10 days & 140 days \\
\hline 4. & 20th,20th Mezz ,21th Floor & Slab Konvensional & - & - \\
\hline 5. & 22nd-58th Floor & 36 floor & 10 days & 360 days \\
\hline 6. & $\begin{array}{c}\text { 59th-62nd floor (South } \\
\text { tower) } \\
\text { 59th-64nd floor(North } \\
\text { tower) }\end{array}$ & Roof & - & - \\
\hline & Times total & \multicolumn{2}{|c|}{ 520 days } \\
\hline
\end{tabular}

(Source :Data in Research Penulis,2020)

In Table 3.2 it can be explained that not all flooring uses metaldeck, on floors 3,4,5,20,20 mezzanine, 21 uses conventional conventional slabs. The use of conventional slabs is caused by bridges and joint connections on the related floor. While on the 59-62 (north tower) and 59-64 (south tower) floors are used as roofs. So from Table 4.5 the temporary supporting installation work using non-reusable methods is 520 days.

\subsubsection{Analysis of the Reusable Method of Ordering Time}

Analysis of the productivity of each job is needed to determine the duration of time needed for each job. Productivity is the ability of tools and workers can complete a job within the work unit's time. Productivity data obtained from interviews with discussion, and data collection. The duration of implementation time is obtained by calculating the duration of installation time on each work item. 
Table 3.3 Productivity of re-usable Installation in 1 Floor

\begin{tabular}{|c|c|c|c|c|}
\hline No & Work item & Time / span & Many Spans & Amount of time \\
\hline a. & $\begin{array}{l}\text { Scaffolding is only } \\
\text { at the end of the } \\
\text { Landscape }\end{array}$ & 50 minutes & 40 span & 2000 minutes \\
\hline b. & $\begin{array}{c}2 \text { point elbow } \\
\text { fabrication }\end{array}$ & 15 minutes & 40 span & 600 minutes \\
\hline c. & Hollow Fabrication & 10 minutes & 40 span & 400 minutes \\
\hline d. & 4 point elbow weld & 45 minutes & 40 span & 1800 minutes \\
\hline e. & Hollow instalation & 5 minutes & 40 span & 200 minutes \\
\hline f. & Unloading hollow & 15 minutes & 40 span & 600 minutes \\
\hline g. & $\begin{array}{l}\text { Unloading } \\
\text { scaffolding }\end{array}$ & 40 minutes & 40 span & 1600 minutes \\
\hline \multicolumn{2}{|c|}{ Total Installation Time } & \multicolumn{3}{|c|}{7200 minutes } \\
\hline
\end{tabular}

(Source :Data in Research Penulis,2020)

From Table 3.3 it can be concluded that the total installation time for all temporary supporting work items using the reusable method per 1 floor is 15200 minutes. So that:

Total Time Completion of All Temporary Supporting Work Items per 1 Floor Using the Reusable Method.

Total turnaround time for all items / hour:

$$
15.200 \text { minutes }=\frac{7200 \text { minutes }}{60 \text { minutes }}=120 \text { hours }
$$

In 1 day there are 2 shifts, with each shift of workers is 8 hours so that the total working time is 16 hours.

$$
\text { Total workmanship for } 1 \text { floor }=\frac{\text { The total turnaround time for all items }}{\text { labor hours }}
$$

Total workmanship for 1 floor $=\frac{120 \text { hour }}{16 \text { hour }}=8$ days

Compensation Overlaping Calculation Between Zones According to Figure $4.3=$

Zone $\mathrm{A} 1=\mathrm{A} 2=\mathrm{B} 1=\mathrm{B} 2=\frac{8 \text { days }}{4 \text { days }}=2$ days +1 days (overlaping perzone $)=3$ days

Total Net Workability $=$ Total completion time - Compensation Overlapping

$$
\text { Total Net Workmanship }=8 \text { hari }-3 \text { hari }
$$

Total Net Workmanship/floor $=5$ days

So that the Total Time Completion of All Temporary Supporting Work Items per 1 Floor Using the Reusable Method is 5 days.

Tabel 3.4 Understanding of Temporary Supporting North \& South Tower

\begin{tabular}{|c|c|c|c|c|}
\hline No & $\begin{array}{c}\text { Data Lantai yang } \\
\text { Menggunakan } \\
\text { Metaldeck }\end{array}$ & $\begin{array}{c}\text { Jumlah lantai } \\
\text { South\&NorthTower }\end{array}$ & $\begin{array}{c}\text { Pengerjaan/ } \\
\text { Lantai }\end{array}$ & $\begin{array}{c}\text { Jumlah } \\
\text { Hari }\end{array}$ \\
\hline 1. & $\begin{array}{c}\text { Lantai 1 Upper -2nd } \\
\text { Floor }\end{array}$ & 2 Lantai & 5 hari & 10 hari \\
\hline 2. & Lantai 3rd -5th Floor & Slab Konvensional & - & - \\
\hline 3. & Lantai 5th-19th Floor & 14 Lantai & 5 hari & 70 hari \\
\hline 4. & $\begin{array}{c}\text { Lantai 20th,20th } \\
\text { Mezz,21th Floor }\end{array}$ & Slab Konvensional & - & - \\
\hline 5. & Lantai 22nd-58th & 36 Lantai & 5hari & 180 hari \\
\hline
\end{tabular}




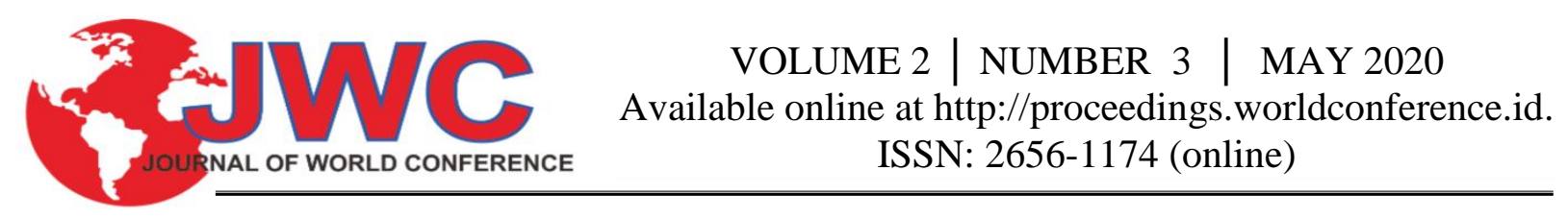

\begin{tabular}{|c|c|c|c|c|}
\hline & Floor & & & \\
\hline 6. & $\begin{array}{l}\text { Lantai 59th-62nd } \\
\text { floor (South tower) } \\
\text { Lantai 59th-64nd } \\
\text { floor(North tower) }\end{array}$ & Roof & - & \\
\hline & Total Time & \multicolumn{3}{|c|}{260 days } \\
\hline
\end{tabular}

(Source :Data in Research Penulis,2020)

it can be explained that not all flooring uses metaldeck, on floors 3,4,5,20,20 mezzanine, 21 uses conventional conventional slabs. The use of conventional slabs is caused by bridges and joint connections on the related floor. While on the 59-62 (north tower) and 59-64 (south tower) floors are used as roofs. from Table 4.7 the temporary supporting installation work using the reusable method is 260 days.

\subsection{ANALYSIS OF MATERIAL UNITS AND WORKERS}

\subsubsection{Unit Price Analysis for Material and Non-Reusable Method Work}

The unit price analysis used as a reference is the standardization of unit price of materials, DKI Jakarta's wages contained in the attachment sheet. After observing the field test the types of material used in the installation work are 100x100x8mm elbows and M12-300 mechanical anchors. To analyze the cost of installing temporary supports using a non-reusable method, see the following table:

Tabel 3.5 Analysis of Wage Unit Prices and Equipment

\begin{tabular}{|c|c|c|c|}
\hline NO & DESCRIPTION & UNIT & PRICE UNIT (Rp) \\
\hline \multicolumn{3}{|c|}{ Pekerja } \\
\hline $\mathbf{1}$ & last Anchor & OH & Rp. 75.000 \\
\hline $\mathbf{2}$ & Blacksmith & OH & Rp. 75.000 \\
\hline \multicolumn{5}{|c|}{ Bahan } \\
\hline $\mathbf{1}$ & Angle 100x100x8mm & $\mathrm{m}^{3}$ & Rp. 585.600/6m \\
\hline $\mathbf{2}$ & $\begin{array}{c}\text { Mechanical Anchor } \\
\text { M12-300 }\end{array}$ & titik & Rp. 75.000 \\
\hline
\end{tabular}

(Sumber :SNI DKI Jakarta,2016)

From field observations to install non-reusable temporary support this method still uses a 100x100mm hollow and the elbows to be anchored. In the installation there are 2 work items. The first item is mounting elbows. For the elbow installation work, it must be noted that in one work floor there are 40 span metaldecks, with each $2.2 \mathrm{~d}$ span metaldeck. In each floor there are 4 elbowmakers and 8 people for each elbow. The second item is the installation of mechanical anchor with type (Anchor M12-300) there are 7 ankle points that must be installed on each floor. The installation requires 5 anchor workers. So that the total material costs and total wages will be calculated as the following table:

Table 3.6 Calculation of the Number of Floors Using Metaldeck

\begin{tabular}{|c|c|c|}
\hline No & Data Lantai yang Menggunakan Metaldeck & $\begin{array}{c}\text { Jumlah lantai } \\
\text { South\&NorthTower }\end{array}$ \\
\hline 1. & 1 Upper -2nd Floor & 2 floor \\
\hline 2. & 3rd -5th Floor & Slab Konvensional \\
\hline 3. & 5th-19th Floor & 14 floor \\
\hline 4. & 20th,20th Mezz,21th Floor & Slab Konvensional \\
\hline 5. & 22nd-58th Floor & 36 floor \\
\hline
\end{tabular}




\begin{tabular}{|c|c|c|}
\hline 6. & $\begin{array}{l}\text { 59th-62nd floor (South tower) } \\
\text { 59th-64nd floor(North tower) }\end{array}$ & Roof \\
\hline \multicolumn{2}{|c|}{ Total Lantai } & 52 floor \\
\hline
\end{tabular}

In Indonesia 1 project there are 2 towers namely South \& North tower. From the above floor data we can calculate the total material price and total wage price as follows:

Table 3.7 Material Installation Method Non-Re-usable (hollow \& anchor) / floor

\begin{tabular}{|c|c|c|c|c|}
\hline No & Uraian & Unit & Harga & Harga Total \\
\hline $\mathbf{1}$ & Siku 100x100x8mm & $2,2 \mathrm{~m}$ & Rp. 585.600/6m & Rp.214.720/span \\
\hline $\mathbf{2}$ & $\begin{array}{c}\text { Mechanical Anchor M12- } \\
\text { 300 }\end{array}$ & 7 titik & Rp. 75.000 & Rp. 525.000/span \\
\hline \multicolumn{3}{|c|}{ Total Material / Span } & Rp. 740.000/span \\
\hline No & Uraian & Unit & Harga & Harga Total \\
\hline $\mathbf{1}$ & North Tower (52 Floor) & 40 span & Rp. 740.000/span & Rp. 1.539.200.000 \\
\hline $\mathbf{2}$ & South Tower (52 Floor) & 40span & Rp. 740.000/span & Rp. 1.539.200.000 \\
\hline \multicolumn{4}{|c|}{ Total Harga Material } \\
\hline
\end{tabular}

(Source :Data in Research Penulis,2020)

Table 3.8 Total Workers Wages Non Re-usable (angle \& hollow) / 1 floor

\begin{tabular}{|c|c|c|c|c|}
\hline No & Uraian & Satuan & Upah pekerja & Harga Total \\
\hline $\mathbf{1}$ & Upah Angkur & $5 \mathrm{OH}$ & Rp. 75.000 & Rp.375.000 \\
\hline $\mathbf{2}$ & Upah Pembuatan Lubang Siku & $4 \mathrm{OH}$ & Rp. 75.000 & Rp. 300.000 \\
\hline $\mathbf{3}$ & Upah Sepasang Siku & $8 \mathrm{OH}$ & Rp. 75.000 & Rp. 600.000 \\
\hline \multicolumn{3}{|c|}{ Total Wages / Floors } & Rp. 1.275 .000 \\
\hline \multicolumn{3}{|c|}{ Wages total 52 floors } & Rp. 66.300.000 \\
\hline \multicolumn{3}{|c|}{ Total Wages For 2 Towers } & Rp.132.600.000 \\
\hline
\end{tabular}

(Source :Data in Research Penulis,2020)

Table 3.9 Total Material Costs and Wages of Workers for Non-Re-usable and Reusable Methods

\begin{tabular}{|c|c|c|}
\hline No & Uraian & Total Biaya \\
\hline 1 & Total Material Prices & $\mathbf{R p . 3 . 0 7 8 . 4 0 0 . 0 0 0}$ \\
\hline 2 & Total Worker's Wages & $\mathbf{R p . 1 3 2 . 6 0 0 . 0 0 0}$ \\
\hline \multicolumn{2}{|c|}{ Non-reusable Total Cost Budget Method } & $\mathbf{R p . 3 . 2 1 1 . 0 0 0 . 0 0 0}$ \\
\hline
\end{tabular}

(Source :Data in Research Penulis,2020)

From the table above calculation, the total material price is Rp. 3,078,400,000.00 and the total price of the workers is Rp.132,600,000.00 so that in the process of installing temporary support using the initial method (non-reusable) a total budget of Rp.3,211,000,000.00 is obtained. 


\subsubsection{Unit Material Analysis and Reusable Method Work}

For the analysis of the cost of installing temporary supports using the reusable method. There are 3 jobs in installing this temporary support. From the writer's observation in the field. The first work of mounting the elbow size of $100 \times 100 \times 8 \mathrm{~mm}$ volume that can be cured is shown in the following table:

Table 3.10 Analysis of Wage Unit Prices and Equipment

\begin{tabular}{|c|c|c|c|}
\hline NO & DESCRIPTION & UNIT & PRICE UNIT (Rp) \\
\hline \multicolumn{4}{|c|}{ The worker } \\
\hline $\mathbf{1}$ & Disassemble Install & OH & Rp. 75.000 \\
\hline $\mathbf{2}$ & Welder & OH & Rp. 150.000 \\
\hline \multicolumn{4}{|c|}{ material } \\
\hline $\mathbf{1}$ & Angle 100x100x8mm & $\mathrm{m}^{3}$ & Rp. 585.600/6m \\
\hline $\mathbf{2}$ & Elektroda E-70XX & titik & Rp. $1.200 .000 / 6 \mathrm{~m}$ \\
\hline $\mathbf{3}$ & Hollow 50x50x4mm & pcs & Rp.540.000/200pcs \\
\hline
\end{tabular}

(Sumber :SNI DKI Jakarta,2020)

Tabel 3.11 Material Usage Method Re-usable (angle \& drop hollow) / floor

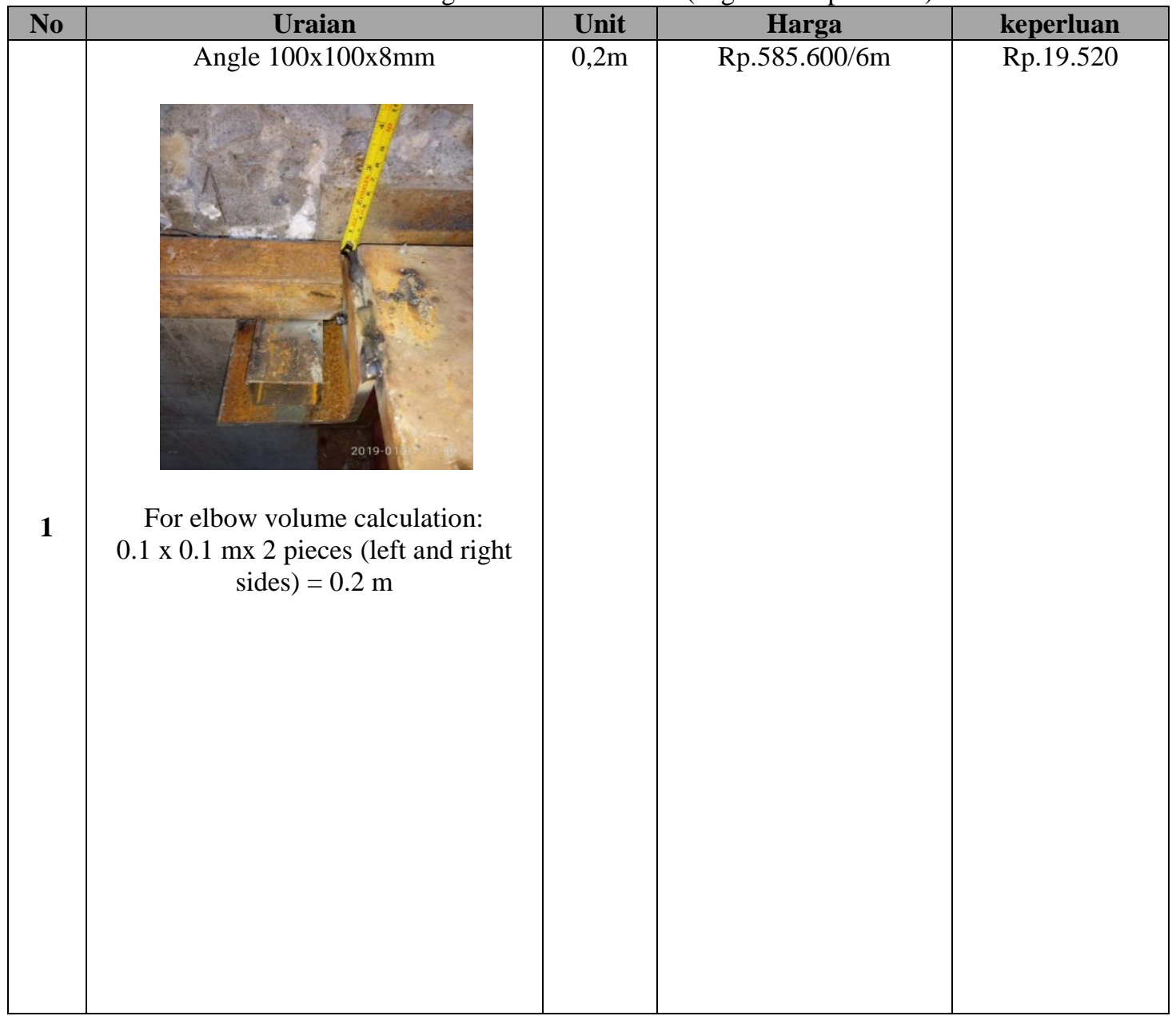




\begin{tabular}{|c|c|c|c|c|}
\hline 2 & $\begin{array}{l}\text { Hollow 50x50x4mm } \\
\text { For the purposes of hollow each span } \\
\text { is } 2.2 \mathrm{~m}\end{array}$ & $2,2 \mathrm{~m}$ & Rp.1.200.000/6m & Rp. 480.000 \\
\hline 3 & Elektroda E-70XX & $2 \mathrm{pcs}$ & Rp.540.000/200pcs & Rp.5.400 \\
\hline & Total Material / Span & \multicolumn{3}{|c|}{ Rp.504.920 } \\
\hline & Total/Floor & \multicolumn{3}{|c|}{ Rp. 20.196.800 } \\
\hline \multicolumn{5}{|c|}{$\begin{array}{l}1 \text { component meets the needs of one floor and can be re-usable as many as } 3 \text { times so, } 52 \text { floors: } \\
\qquad 3 \text { usage }=13 \mathrm{x}\end{array}$} \\
\hline \multicolumn{5}{|c|}{ Rp. 20.196.800 $\times 13$ times the use of reusable $\times 2$ tower } \\
\hline & Total Price & \multicolumn{3}{|c|}{ Rp. 525.116.800 } \\
\hline
\end{tabular}

(Source :Data in Research Penulis,2020)

Tabel 3.12 Total Wages of Reusable Workers (angle \& drop hollow) / floor

\begin{tabular}{|c|c|c|c|c|}
\hline No & Description & Unit & Worker's wages & Final price \\
\hline 1 & $\begin{array}{c}\text { Unloading \& Install Hollow } \\
\text { Wages }\end{array}$ & 8org & Rp. 75.000 & Rp.600.000 \\
\hline 2 & Wages for welding work & 4org & Rp. 150.000 & Rp. 600.000 \\
\hline \multicolumn{4}{|c|}{ Total Wages / Floors } & Rp. 1.200 .000 \\
\hline \multicolumn{4}{|c|}{ Wages total 52 floors } & Rp. 62.400 .000 \\
\hline \multicolumn{4}{|c|}{ Total Wages For 2 Towers } & Rp.124.800.000 \\
\hline
\end{tabular}

(Source :Data in Research Penulis,2020))

Tabel 3.13 Total Biaya Material dan Upah Pekerja Metode Re-usable

\begin{tabular}{|c|c|c|}
\hline No & Description & Total cost \\
\hline 1 & Total Material Prices & Rp. 525.116.800 \\
\hline 2 & Total Worker's Wages & Rp. 124.800.000 \\
\hline \multicolumn{2}{r|}{ Reusable Total Cost Method Cost } & Rp.649.916.800 \\
\hline
\end{tabular}

(Source :Data in Research Penulis,2020)

\subsection{DISCUSSION OF WORK TIME RESULTS}

From the results of the analysis of the work time above shows clearly that the temporary supporting installation work using the reusable method (angle \& drop hollow) is more efficient and effective than the nonreusable system (anchor \& hollow). This is because the work of temporary supporting installation using nonreusable methods (anchor $\&$ hollow) requires some quite expensive materials and also installation that is quite difficult if done only with 1 worker. So the time used in the installation process is inefficient compared to the 
reusable method. The reusable method itself only requires 1 worker for the $50 \times 50 \mathrm{~mm}$ hollow installation process so that work can be completed faster. The time difference of the temporary supporting installation work uses the non-reusable method with the reusable as follows:

Tabel 3.14 The time difference between installing temporary supporting methods is non-reusable and reusable

\begin{tabular}{|c|c|c|c|}
\hline \multirow{2}{*}{ DESCRIPTION } & \multicolumn{2}{|c|}{ WORK TIME PLAN } & \multirow{2}{*}{ DIFFERENCE } \\
\cline { 2 - 3 } & non-reusable & reusable & \multirow{2}{*}{ TIMES } \\
\hline \multirow{2}{*}{ T20 days } & 260 days & \\
\hline
\end{tabular}

(Source :Data in Research Penulis,2020)

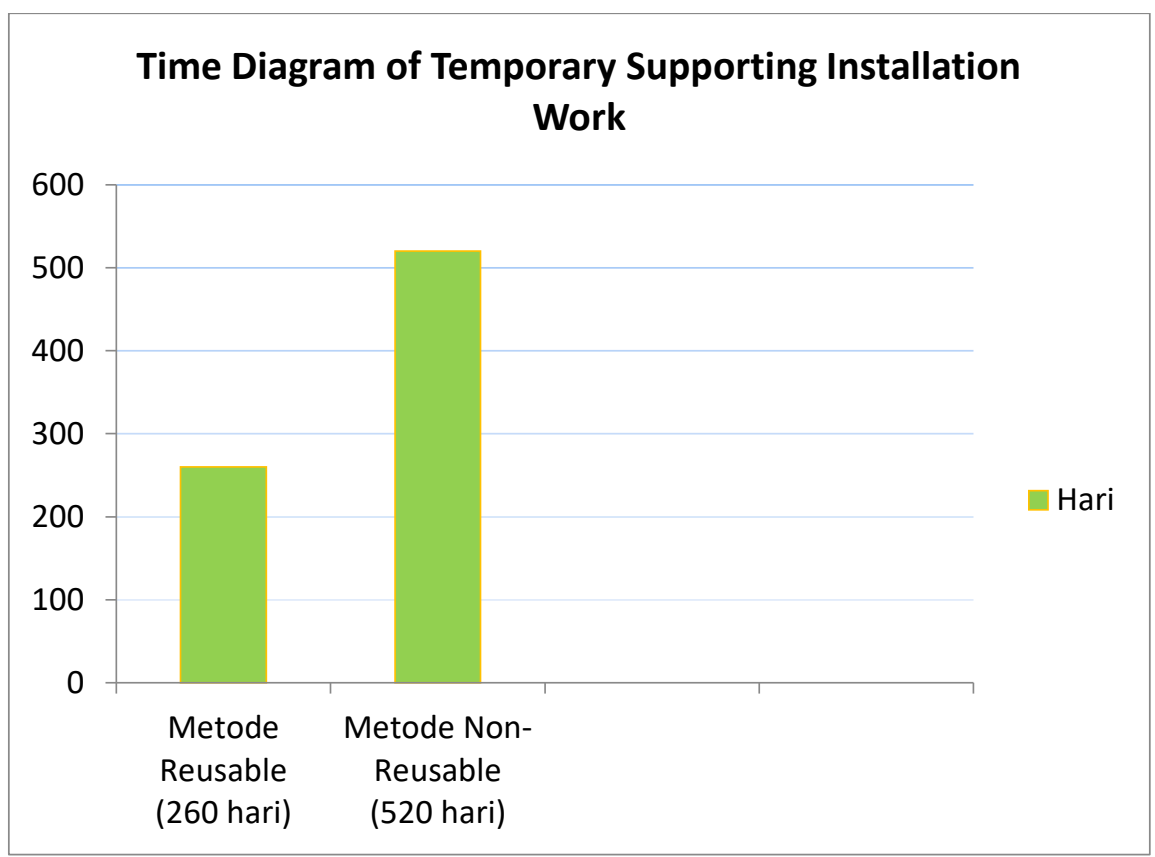

(Source :Data in Research Penulis,2020)

Gambar 3.1 Time Difference Installation Chart Temporary Supporting Reusable and non-reusable methods

From the timeframe diagram it can be concluded that installation of welded angle \& drop hollow using the reusable method above saves 260 days of work time.

\subsection{DISCUSSION OF WORK COST RESULTS}

From the calculation results, obtained the cost of temporary support installation work using a nonreusable method of Rp.3,211,000,000.00. As for the cost of implementing temporary support installation using the reusable method Rp.649,916,800.00. There is a difference in the cost between the temporary supporting installation work with the non-reusable and reusable methods of Rp. 2,561,083,200. Where for the cost of implementing a temporary supporting installation with a reusable method is cheaper than the non-reusable method. Comparison of the prices of the two temporary supporting systems in the installation of the metaldeck slab is due to the high price of material and wages of workers. So that the reusable system is very effective in the Indonesian project 1 .

Table 3.15 Differences in installation time for temporary supporting non-reusable and reusable methods 


\begin{tabular}{|c|c|c|c|}
\hline \multirow{2}{*}{ DESCRIPTION } & \multicolumn{2}{|c|}{ BUDGET PLAN } & \multirow{2}{*}{ DIFFERENCE } \\
\cline { 2 - 3 } & non-reusable & reusable & \multirow{2}{*}{ Rp.2.561.083.200 } \\
\hline \multirow{2}{*}{ COST } & Rp.3.211.000.000 & Rp.649.916.800 & \\
\hline
\end{tabular}

(Source :Data in Research Penulis,2020)

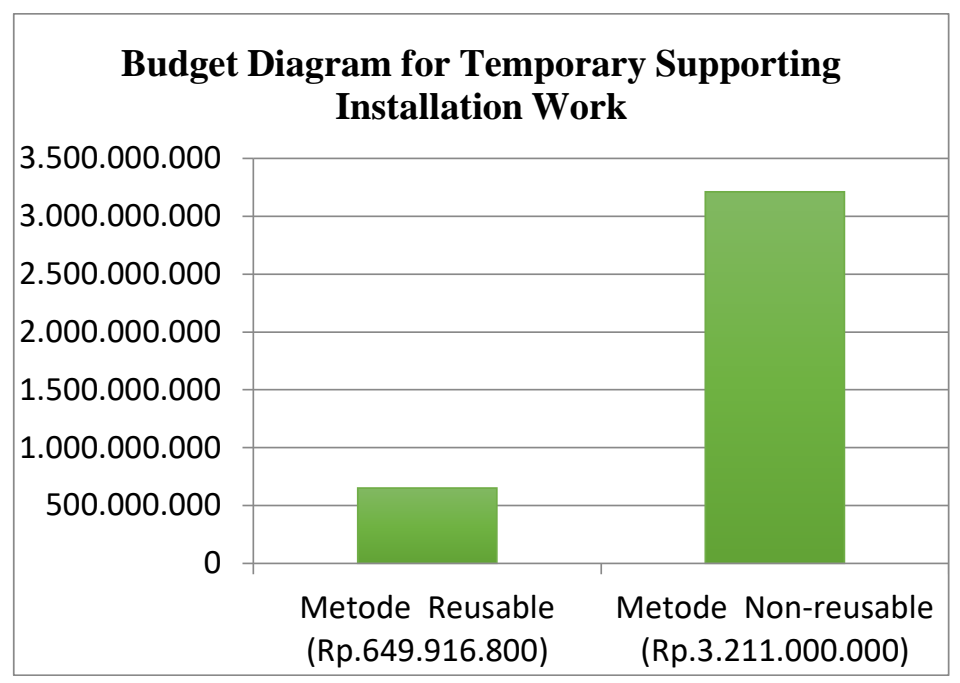

(Source :Data in Research Penulis,2020)

Figure 3.2 Graph Difference in the Cost of Temporary Supporting Installation Costs Reusable and non-reusable methods

\section{CONCLUSIONS AND SUGGESTIONS}

\subsection{CONCLUSION}

Based on the observation and analysis of the use of welded angle $\&$ drop hollow as reusable temporary supporting on the slab metaldeck in terms of cost and time performance, it can be concluded:

1. From the results of the time and cost analysis of the work above, it is clear that Temporary Support work using a welded angle \& hollow drop is more effective and efficient than using the non-reusable initial method (hollow \& anchor).

2. From a detailed calculation the use of Welded Angle \& Drop Hollow as Reusable Temporary supporting saves costs up to Rp. 2,561,083,200.00. Meanwhile, in terms of time, it is also 260 days faster. The installation process is easy, minimizes material in a price and in accordance with standards in the field greatly affects time and cost performance. So this method is very feasible to be implemented in the field.

\subsection{SUGGESTIONS}

From the results of research, analysis and discussion as well as conclusions drawn, it can be suggested: 1. More specific research and planning needs to be done to consider which method is more efficient in each of the projects reviewed, because the field conditions in the project are different. Researchers still take into account the suitability of the materials used in the field so the calculations will be different if using other materials. Alternative use of material can save costs and time on project work, however, it must still be considered in accordance with applicable standards.

2. A further study needs to be done on the time or duration of work carried out in terms of the hollow \& welded angle mounting work area as a temporary supporting that is ready to be carried out and not yet considering other interrelated jobs including metaldeck installation, 
hairpin wairemesh and extra reinforcement. So it is good if reviewed other work that affects the duration of the installation of temporary support.

3. Further research needs to be done so that it can be seen the impact of the time that occurs from the selection of methods used need to be included in the total time of the overall construction of the building being reviewed.

\section{References}

Dewi, AA., 2010. Identifikasi Faktor - Faktor Profesionalisme Manajer Proyek Pada Proyek Konstruksi. Jurnal Ilmiah Teknik Sipil. Vol 14, Hal 74 - 81. Denpasar

Jhonnadi. 2017

Hardiyatmo, H.C. 2011. Analisis dan Perancangan Fondasi I, Gadjah Mada UniversityPress, Yogyakarta.

Ir.Agus Suroso,MT .2019. Kajian Biaya dan Waktu Pelaksanaan Sistem Ground Anchor Sebagai Pengganti Sistem Strutting Pada Proyek Gedung Markas Besar Polri Sisi Barat. Universitas Mercubuana ,Jakarta.

Jhonnadi. 2017. Analisis Faktor - Faktor Yang Mempengaruhi Biaya Dalam Perubahan Sistem Strutting Baja Menjadi Ground Anchor (Studi Kasus Proyek Apartemen Grand Mansion Borobudur), Jakarta : Universitas Mercu Buana Jakarta.

Kerzner, Harold. 2006. Project Management : A system Approach to Planning, shedulling, and controlling, John and Wiley. Inc. Ninth Edition. New Jersey. Larson, E.W. and Gray, C.F. 2011, Project Management: The Managerial 51 Process, McGraw-Hill/Irwin, New York, NY.

Kerzner, Harold. 2006. Project Management : A system Approach to Planning, shedulling, and controlling, John and Wiley. Inc. Ninth Edition. New Jersey.

Kurniawan, Ferry.2017. Analisis Perbandingan Waktu, Biaya, dan Direct Waste Penggunaan Tulangan Konvensional, Wiremesh, dan Floordeck pada Pekerjaan Pelat Lantai, Unversitas Diponegoro, Semarang.

Larson, E.W. and Gray, C.F. 2011, Project Management: The Managerial 51 Process,McGraw-Hill/Irwin, New York, NY.

Pradisa, Rino. 2016. Analisis Stabilitas Galian Basement Dengan Diaphragm Wall Proyek Millennium Centennial Center Sudirman Jakarta Selatan. Jakarta :Universitas Mercu Buana Jakarta.

Naray, Farly.2015. Analisa Perencanaan dan Pelaksanaan Pelat Bondek Sebagai Pengganti Tulangan Tarik Konstruksi Pelat Lantai Pada Proye Pembangunan Gedung Kuliah Terpadu Politeknik Negeri Manado, Politeknik Negeri Manado.

Rani, Hafnidar A. 2016. Manajemen Proyek Konstruksi. Yogyakarta: CV. Budi Utama Suryani. 2011. Analisa pengaruh financing To Deposit Ratio (FDR) TerhadapProfitabilitas Perbankan Syariah di Indonesia, STAIN Malikkussaleh Lhokseumawe.Thoengsal, J. 2016. Dinding Penahan, Makasar :Universitas Teknologi Sulawesi

Rani, Hafnidar A. 2016. Manajemen Proyek Konstruksi.CV. Budi Utama, Yogyakarta.

SDI.2011.Steel deck Institude Manual of Construction with Steel deck

Siti, Tuti . 2018. Perbandingan Biaya Pelaksanaan Pelat Beton Bondek Dengan Pelat Konvensional pada Gedung Hotel Bhayangkara Yogyakarta. Universitas Islam Indonesia, Yogyakarta

Suryani. 2011. Analisa pengaruh financing To Deposit Ratio (FDR) Terhadap Profitabilitas Perbankan Syariah di Indonesia, STAIN Malikkussaleh Lhokseumawe.

Wijayanto, Afik .2018. Alternatif Review Design Pekerjaan Dinding Bata Ringan Menjadi Dinding Wall Block (Studi Kasus Proyek Pembangunan “Universitas Trisakti” di Sentul City), Univeritas Mercubuana, Jakarta. 


\section{Biographies}

Novika Chandra Fertilia, ST, MT was born in Belitang on November 12, 1989. Entered the university of Lampung in 2012 in the Faculty of Engineering, Department of Civil Engineering and took the thesis title "Project Scheduling with Primavera Project Planner". In 2016, he continued his Masters program at the University of Indonesia, Jakarta with a major in civil engineering and took the title "PMBOK-Based Project Planning".

Sani Sona Swasti was born in Yogyakarta,a capital Special Region Of Yogyakarta in September 1995.After graduation a vocational high school education in majoring in building drawings and graduated from Yogyakarta 2 vocational high school in 2014. In 2016 continued to study at Mercubuna University Jakarta took the engineering faculty majoring in civil engineering and took the title "Analysis of Using Welded Angle\&Drop Hollow As Reusable Temporary Supporting in Metaldeck Slabs Viewed From Performance Of Cost And Time" 